\title{
Prevalence and reproduction of Tropilaelaps mercedesae and Varroa destructor in concurrently infested Apis mellifera colonies
}

\author{
Ninat BuawangPOnG ${ }^{1}$, Lilia I. de GuZman ${ }^{2}$, Kitiphong Khongrhinitbunjong ${ }^{1}$, \\ Amanda M. Frake ${ }^{2}$, Michael Burgetr ${ }^{3}$, Panuwan Chantawannakul $^{1}$ \\ ${ }^{1}$ Department of Biology, Faculty of Science, Chiang Mai University, Chiang Mai 50200, Thailand \\ ${ }^{2}$ Honey Bee Breeding, Genetics and Physiology Laboratory, USDA-ARS, 1157 Ben Hur Road, Baton Rouge, LA 70820, \\ USA \\ ${ }^{3}$ Department of Horticulture, Oregon State University, Corvallis, OR 97331, USA
}

Received 19 June 2014 - Revised 25 March 2015 - Accepted 14 April 2015

\begin{abstract}
The prevalence of Tropilaelaps mercedesae and Varroa destructor in concurrently infested A. mellifera colonies in Thailand was monitored. We also assessed the fecundity of T. mercedesae and $V$. destructor in naturally infested brood and in brood cells deliberately infested with both mite genera. Results showed that the natural co-infestation of an individual brood cell by both mite genera was rare $(<0.1 \%)$. Overall, T. mercedesae was the more dominant brood parasite of A. mellifera than V. destructor. In naturally infested brood, the proportion of nonreproductive Tropilaelaps $(29.8 \pm 3.9 \%)$ was lower than that of Varroa $(49.6 \pm 5.9 \%)$. Both mites produced similar numbers of progeny ( $T$. mercedesae $=1.48 \pm 0.05$; V. destructor $=1.69 \pm 0.14$ ). The two mite genera also reproduced normally when they were deliberately introduced into the same brood cells. In two separate assessments, the average worker brood infestations of T. mercedesae $(19.9 \%)$ were significantly higher than that of V. destructor $(0.7 \%)$. Our results on the higher prevalence and reproductive ability of T. mercedesae in concurrently infested colonies reaffirm Tropilaelaps ' competitive advantage over $V$. destructor and their reported negative impact to $A$. mellifera colonies.
\end{abstract}

\section{Apis mellifera / Tropilaelaps mercedesae / Varroa destructor / concurrent infestation / seasonal abundance}

\section{INTRODUCTION}

Varroa destructor and Tropilaelaps have been co-infesting A. mellifera colonies for about 50 years in Asia (Delfinado 1963). However, infestations of $T$. clareae (likely referring to T. mercedesae) were higher than those of $V$. jacobsoni (likely referring to $V$. destructor ) in Thailand (Burgett et al. 1983). Similar trends were observed in Afghanistan and Vietnam (Woyke 1987a, 1989). However, in the Philippines, those

Corresponding author: P. Chantawannakul, panuwan@gmail.com

Handling Editor: Yves Le Conte
A. mellifera colonies that had higher infestations of $T$. clareae than Varroa in April had higher Varroa than T. clareae infestations in September (Fajardo and Cervancia 2004). In Northern Thailand, Kavinseksan et al. (2003) monitored T. clareae (probably referring to T. mercedesae) infestations in mite-inoculated colonies of Primorsky bees (=Russian honey bees, RHB) and Thai A. mellifera. The author found that RHB colonies (mean $=18.5 \%$ ) supported higher brood infestation than the local bees (mean= $11.4 \%$ ) with the highest infestations observed in May $(\mathrm{RHB}=33 \%$, Thai A. mellifera $=21 \%)$. Factors that influence population fluctuations of both mites in concurrently infested colonies have not been studied. 
Although both $V$. destructor and $T$. mercedesae are observed in infesting colonies, T. mercedesae is considered to be a more serious problem of A. mellifera colonies than Varroa mites in Northern Thailand (Burgett et al. 1983; Anderson and Morgan 2007). This discrepancy in severity may be due to differences in their abilities to compete for honey bee hosts and reproduce within brood cells. In this study, we monitored the build-up and synchronization in the populations of both $V$. destructor and T. mercedesae in concurrently infested A. mellifera colonies. Reproduction was also assessed in naturally infested brood and in brood cells deliberately infested with both mite genera to determine if variation in reproduction exists. Knowledge on differential reproduction may help explain population fluctuations, competitive advantage, or virulence of one mite species.

\section{MATERIALS AND METHODS}

\subsection{Experiment 1: brood infestations of $V$. destructor and $T$. mercedesae in concurrently infested $A$. mellifera colonies}

Observations were conducted using 16 colonies housed in 10-frame Langstroth hives from September 2011 to September 2012. No acaricidal treatments were applied to the colonies during the course of the study. All queens were hybrids based on an Italian honey bee (A. $m$. ligustica). The brood area $\left(\mathrm{cm}^{2}\right)$ was determined by visual estimation of comb area covered by capped brood (Rogers et al. 1983). Mite infestation parameters were determined by randomly examining 50-100 worker brood cells from each colony on a monthly schedule (de Guzman et al. 2007). Stages of mite progeny were differentiated and recorded.

Since the results of the 13-month observation showed rare co-infestations of both Tropilaelaps and Varroa mites, we decided to confirm our observation by examining three additional concurrently infested A. mellifera colonies. For each colony, different stages of worker and drone brood were examined for the presence or absence of these two parasitic mites. Adult bee infestation was also determined by sampling about $400-500$ bees per colony and washed with soapy water to remove mites (Rinderer et al. 2004). The mites were collected and then differentiated according to species.

\subsection{Experiment 2: comparative reproduction of $V$. destructor and $T$. mercedesae in artificially inoculated brood}

During the conduct of experiment 1, we rarely observed brood cells that were infested with both Tropilaelaps and Varroa. This experiment sought to investigate mite reproduction when both Tropilaelaps and Varroa were deliberately introduced into the same brood cells. To provide colonies as free of mites as possible, eight previously acaricide-treated A. mellifera colonies were used in this study (taufluvalinate was used as acaricide in the bee colonies). To obtain brood of the same age, each queen was caged over an empty comb for $24 \mathrm{~h}$ by using a push-in cage ( 8 mesh screen) providing a brood area of about 400 brood cells. On the eighth day when brood cells were capped, one foundress $T$. mercedesae and one $V$. destructor were introduced into the same brood cell. All inoculum foundress mites (dark in color) were collected from tan-bodied pupae of highly infested A. mellifera colonies. Inoculum Tropilaelaps were first examined under a dissecting microscope to exclude males. To inoculate newly sealed larvae, the mite transfer technique was used (Garrido and Rosenkranz 2003; Kirrane et al. 2011; Khongphinitbunjong et al. 2013). Nine days following mite inoculation, the brood cells containing tan-bodied pupae were opened to assess mite reproduction. All stages of mites were differentiated.

\subsection{Mite reproductive status}

For experiment 1, reproductive foundress Tropilaelaps and Varroa mites were those that had at least one progeny. Experiment 2 used two criteria to assess the proportions of nonreproductive foundress mites in order to compare the results of previous studies (de Guzman et al. 2007; Khongphinitbunjong et al. 2013). For criteria 1, reproductive foundress Varroa mites were those that produced an adult male and young daughter or viable offspring (de Guzman et al. 2008). Since Tropilaelaps mites have shorter life cycle when compared to Varroa, it is possible that Tropilaelaps foundress may lay more eggs which can develop to adult offspring by the time of the bee emergence (Sihag 1988; Sammatoro et al. 2000). Woyke (1987a) reported that Tropilaelaps was also able to copulate outside the natal cell. Thus, reproductive foundress 
Tropilaelaps mites were those that had at least one progeny (Khongphinitbunjong et al. 2013). For criteria 2 , regardless of the mites' mating behavior, reproductive foundress Varroa or Tropilaelap s were those that produced $\geq 1$ progeny.

\subsection{Data analyses}

For experiment 1 , only brood cells infested with either T. mercedesae or $V$. destructor were considered for statistical analyses. Prior to analyses, data on the percentage infestation and percentage nonreproduction (NR) were transformed using an arcsine square-root transformation. A repeated measures analysis of variance (ANOVA) with observation dates and mite type as the main effects was performed to determine differences in infestations of both mite types through time. A $z$-test for proportions was used to compare the overall nonreproductive status for both mite species. A one-way ANOVA was used to determine infestation trends of $V$. destructor and T. mercedesae and the amount of brood in the colony through time.

For experiment 2, a $z$-test for two proportions was used to compare reproduction success between the two mite genera. Differences in the reproductive status for each trial were compared using the Marascuillo procedure for multiple proportions (http://www.itl.nist.gov/ div898/handbook/prc/section4/prc474.htm). A paired sample $t$ test was used to compare differences in the number of progeny produced by foundress Tropilaelaps and Varroa mites.

\section{RESULTS}

\subsection{Experiment 1: infestations of $V$. destructor and $T$. mercedesae in concurrently infested $A$. mellifera colonies}

The test colonies reared brood continuously during the experimental period. The highest numbers of sealed brood cells were recorded in March to June 2012 (Figure 1) $\left(F_{11,178}=4.63\right.$, $P<0.0001)$. Of the 18,250 worker brood cells examined throughout this experiment, only 13 brood cells $(<0.1 \%)$ were found to be concurrently infested with both $V$. destructor and T. mercedesae. Of the 970 infested brood cells, $24 \%$ were infested with Varroa, while $76 \%$ were infested by Tropilaelaps . Only nine colonies (out of 16 colonies) produced drone brood during the experiment. In total, 506 drone brood cells were produced throughout the experiment, and all were examined. Only 13 drone cells $(2.6 \%)$ were infested with Tropilaelaps, and 78 (15.4\%) were infested with Varroa mites.

Our results showed significant effects of both mite type $\left(F_{1,13}=42.75, P<0.0001\right)$ and date of observations $\left(F_{12,137}=5.80, P<0.0001\right)$ for the prevalence of both mite genera. Since there was a significant interaction between mite type and date of observation $\left(F_{12,136}=4.39, P<0.0001\right)$, the differences in infestation rates between mite genera were determined for each date of observation. Initially in September 2011, the colonies began with a significantly higher infestation of Tropilaelaps $(10.6 \pm 2.8 \%)$ than Varroa $(2.1 \pm$ $1.0 \%)\left(F_{1136}=20.94, P<0.0001\right)$ (Figure 2$)$. Thereafter, infestation levels of both mite genera decreased significantly although Tropilaelaps infestations remained higher than those of Varroa from October, November, and December 2011 $\left(F_{1136}=23.55, P<0.0001 ; F_{1136}=8.76, P=\right.$ $0.0036 ; F_{1136}=4.74, P=0.0311$, respectively). Infestation by Tropilaelaps significantly decreased in January 2012, slightly increased in February 2012 with a small peak in March 2012, a gradual decrease in April 2012 and a steep decline in May 2012. However, infestations by Tropilaelaps and Varroa were similar during these months (January, $F_{1136}=0.22, P=0.6374$; February, $F_{1136}=0.41, P=0.5253$; April, $F_{1136}=$ 3.06, $P=0.0823$; May, $F_{1136}=0.72, P=0.3987$ ) except in March 2012 when Tropilaelaps had higher infestation than Varroa mites $\left(F_{1136}=\right.$ $4.24, P=0.0413)$. Infestations by both mite species remained similarly low in June $2012\left(F_{1136}=\right.$ $5.26, P=0.0233)$. At this time, only four of the 15 surviving colonies were infested. Although infestation by Varroa increased in July 2012, no difference in the rates of infestation between the mite species was observed $\left(F_{1136}=2.54, P=0.1135\right)$. Infestation by both mite species similarly decreased in August $\left(F_{1136}=2.82, P=0.0957\right)$ when only 11 colonies were sampled because several colonies were too weak to sample. Infestations increased again in September 2012 with Tropilaelaps having a higher rate of infestation 


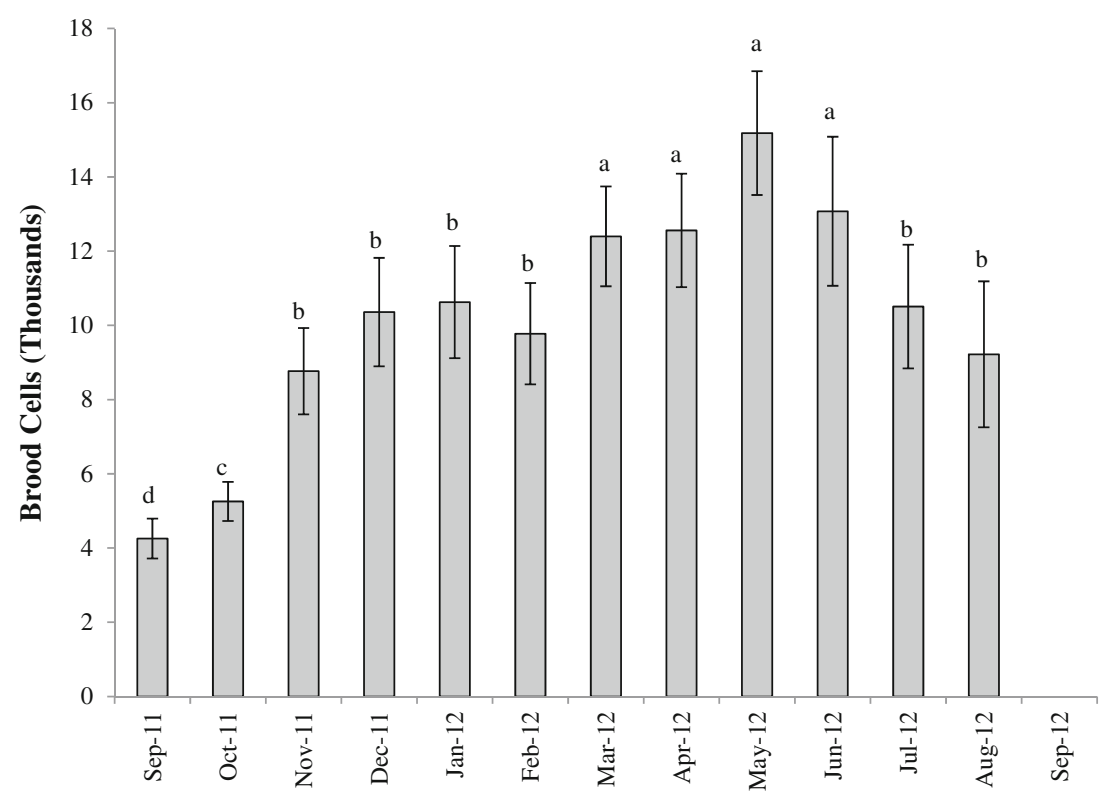

Figure 1. The average number (mean $\pm \mathrm{SE}$ ) of sealed worker brood cells for the 16 colonies monitored for 13 months.

than Varroa $\left(F_{1136}=15.21, P=0.0002\right)$. Howev- $\quad$ area $\left(\mathrm{cm}^{2}\right)$ and Tropilaelaps infestation $(r=$ er, there were only four colonies remained alive or $-0.248 ; P=0.0007)$. No correlation between strong enough to sample at this time. There was a brood area and Varroa infestation was detected significant negative correlation between brood $\quad(r=0.023 ; P=0.752)$.

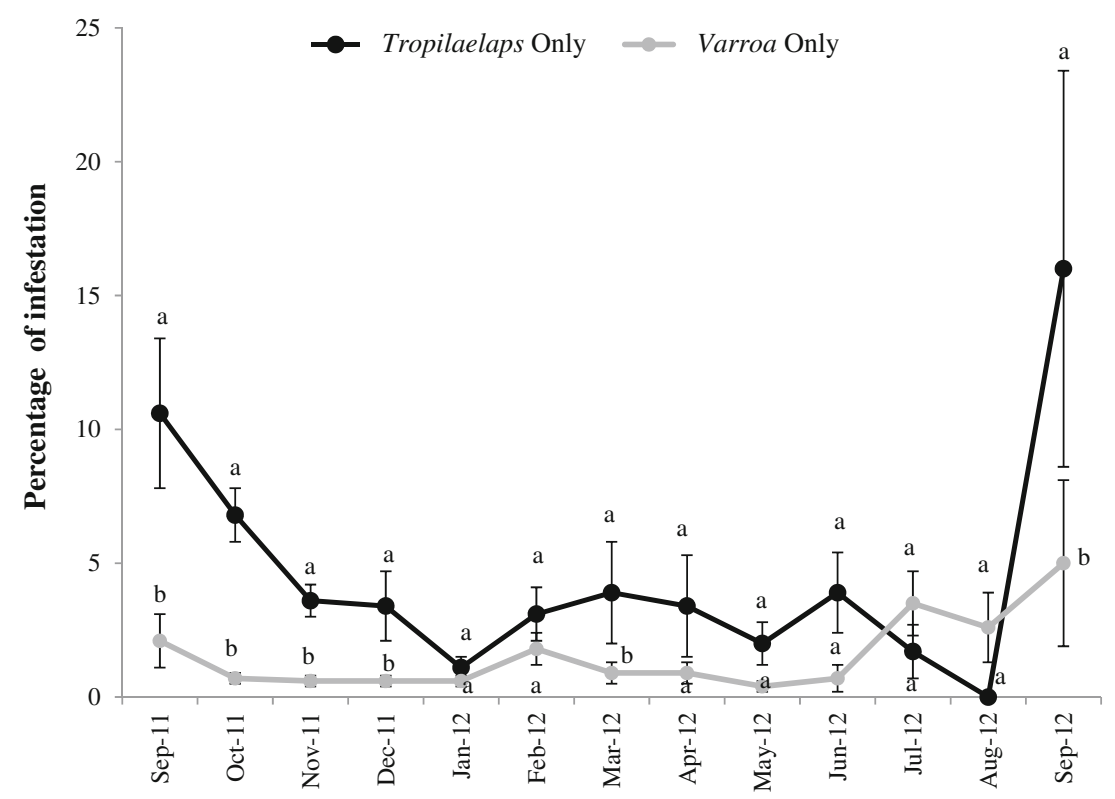

Figure 2. Prevalence (mean $\pm \mathrm{SE}$ ) of $T$. mercedesae and $V$. destructor in worker brood cells of concurrently infested A. mellifera colonies through time. 
A separate examination of three concurrently infested colonies showed a similar trend. Out of the 1230 worker brood cells examined, only four cells $(0.3 \%)$ were concurrently infested. Tropilaelaps was the more predominant mite species than Varroa mites in worker brood cells with an average infestation of $19.9 \%$ (Tropilaelaps) and $0.7 \%$ (Varroa). Varroa (2.5\%) infestation was numerically higher than that of Tropilaelaps $(1.9 \%)$, and no concurrent infestation was observed in the drone brood ( $n=481$ cells). Adult bee infestation was also low: Tropilaelaps $=$ $0.31 \%$ and Varroa $=0.16 \%$.

Proportion of nonreproductive mitesANOVA revealed significant mite type $\left(F_{1,13}=15.05 ; P=\right.$ $0.0019)$ and date of observation $\left(F_{12,95}=3.29\right.$; $P=0.0005)$, but no two-way interaction $\left(F_{11,24}=\right.$ $1.41 ; P=0.2311)$ for the proportion of NR foundresses was detected (Figure 3). Regardless of mite type, the highest proportion of NR foundresses were observed in January 2012 and the lowest NR in November 2011. Overall, there were more Varroa mites that did not reproduce as compared to Tropilaelaps. Further, both mites produced similar number of progeny when observed in purple-eyed and tan-bodied pupae (Tropilaelaps $=1.48 \pm 0.05 ;$ Varroa $=1.69 \pm 0.14$ progeny per foundress) $(t=0.88, P=0.381)$.

\subsection{Experiment 2: reproduction of $V$. destructor and $T$. mercedesae in deliberately infested worker brood}

Our results showed that the reproduction of Tropilaelaps and Varroa was similar in brood cells ( $n=254$ tan-bodied pupae) deliberately infested with both mite species $(z=1.84$, $P<0.01$ ). In addition, $45 \%$ (criteria 1: Varroa mites had one adult male and daughter, while Tropilaelaps mites had at least one progeny) or $52 \%$ (criteria 2: Varroa or Tropilaelap s had those which produced $\geq 1$ progeny) supported reproduction of both mites (Table I). Only $15 \%$ of the inoculated brood cells had both mites that did not

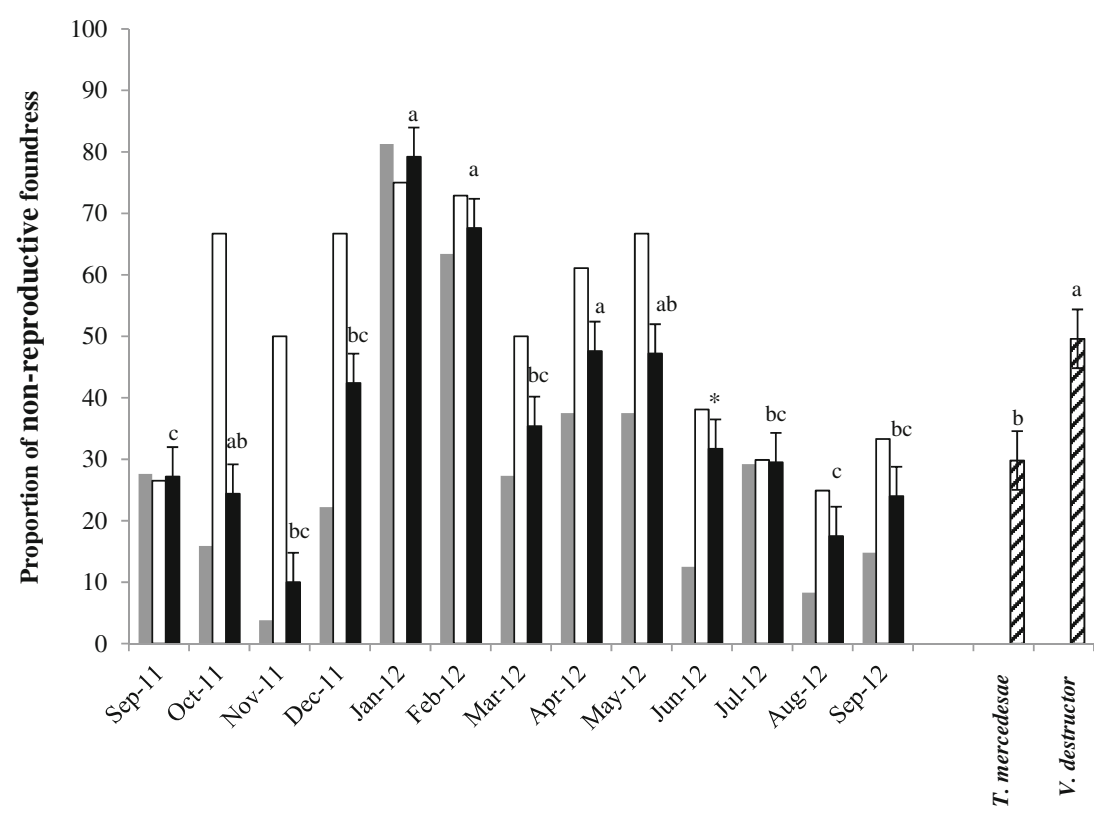

Figure 3. Proportion (mean \pm SE) of nonreproductive foundress (did not produce any progeny) in naturally infested brood cells. Black bars indicate the proportions of nonreproductive (NR) foundress regardless of mite species, gray bars for NR T. mercedesae, and white bars for NR V. destructor for each month of observation. Striped bars represent the average NR for $T$. mercedesae and $V$. destructor (infested colonies $=16$ ). June was nonestimable in the means comparison because of low sample size (infested colonies $=4$ ) (asterisk). 
Table I. Reproduction of $T$. mercedesae $(\mathrm{T})$ and $V$. destructor $(\mathrm{V})$ when co-inhabiting single host pupa $(n=254$ brood cells that were deliberately infested).

\begin{tabular}{lll}
\hline Reproductive status & Criteria 1 & Criteria 2 \\
\hline VNR, TNR & $18.1 \%(n=46)$ & $15.0 \%(n=38)$ \\
VNR, TR & $24.0 \%(n=61)$ & $17.3 \%(n=44)$ \\
VR, TNR & $13.0 \%(n=33)$ & $16.1 \%(n=41)$ \\
VR, TR & $44.9 \%(n=114)$ & $51.6 \%(n=131)$
\end{tabular}

Criteria $1=$ reproductive Varroa produced adult male and young daughter; reproductive Tropilaelaps had $\geq 1$ progeny. Criteria $2=$ reproductive Varroa and Tropilaelap s produced $\geq 1$ progeny

$R$ reproductive; $N R$ nonreproductive; $V N R$, TNR both $V$. destructor and T. mercedesae foundress are nonreproductive; $V N R, T R V$. destructor foundress is nonreproductive but T. mercedesae is reproductive; VR, TNR V. destructor foundress is reproductive but T. mercedesae is nonreproductive; $V R, T R$ foundress of both mite species are reproductive

produce any progeny. $V$. destructor produced more progeny per foundress $(2.2 \pm 0.1)$ than did T. mercedesae $(1.5 \pm 0.1)(t=5.31, P<0.0001)$ in concurrently infested hosts.

\section{DISCUSSION}

V. destructor and Tropilaelaps have been coinfesting A. mellifera colonies for about 50 years in Asia (Delfinado 1963). Our investigation demonstrates that $T$. mercedesae is competitively superior to $V$. destructor mites in concurrently infested A. mellifera colonies in Northern Thailand. The infestation rates by both mite genera fluctuated throughout the study and showed almost identical patterns. Based on our two assessments, the abundance of Tropilaelaps than Varroa observed in this study agreed with previous observations stating that Tropilaelaps mites outcompete Varroa mites in A. mellifera colonies (Burgett et al. 1983; Pettis et al. 2012). However, our observation is in contrast to what has been shown in South Korea where $V$. destructor infestation rates are greater than Tropilaelaps infestation (Lee et al. 2005). It is also possible that the dramatically different climatic conditions for Korea (temperate) compared to Thailand (tropical) are largely responsible for this discrepancy in prevalence. For example, the environmental conditions in Pakistan allow continuous rearing of brood and thus survival of Tropilaelaps
(Waghchoure-Camphor and Martin 2009). According to these authors, T. clareae (likely referring to $T$. mercedesae based on species distribution reported by Anderson and Morgan 2007) infestations coincide with the increase in brood production (April to May). In our study, we found a negative correlation between the amount of brood and Tropilaelaps infestation, which corroborated the findings of Kavinseksan et al. (2004)). This decrease in infestations with the increase in brood production may reflect the "dilution" effect observed in the case of Acarapis mites (de Guzman and Burgett 1991). These authors explained that the parasite infestation rate cannot increase at the same rate as the host population.

The dominance of Tropilaelaps over Varroa may also be influenced by their ability to reproduce. Overall, both mites produced similar numbers of progeny on average. However, higher proportion of Tropilaelaps (70\%) than Varroa (50\%) produced at least one progeny. This ability to reproduce even just one progeny may increase the population of Tropilaelaps faster than Varroa mites.

Varroa is known to prefer drone brood about three to eight times more than worker brood (Fuchs and Langenbach 1989). Thus, the overall low infestation of Varroa mites may be associated with the minimal production of drone brood during this study. In contrast, T. clareae infests 
worker brood about1.5 times more than drone brood (Woyke 1987b). When infesting its indigenous host, A. dorsata, T. mercedesae did not exhibit host sex preference, i.e., drone and worker brood experienced similar infestation rates (Buawangpong et al. 2013). In this study, only a few of the colonies produced drone brood (total $=$ 506) throughout the experiment. Nevertheless, the infestation rate of drone brood by Varroa mites was 3.6 times more than worker brood. For Tropilaelaps mites, the infestation rate of worker brood was 9.4 times greater than that of drone brood. However, we cannot conclude whether or not Tropilaelaps prefer worker over drone brood because of limited production of drone brood.

The co-infestation of a single host by Tropilaelaps and Varroa is rare, an observation also reported by Ritter and SchneiderRitter (1988) and Burgett et al. (1989) with the Acarapis species complex. In general, insect frass and its volatile components provide cues in habitat location (Weiss 2006). In this study, avoidance of an infested cell may be one of the reasons for such a low mixedgenera infestation. It is possible that a blend of chemicals or volatiles produced by the resident Tropilaelaps itself or from their feces and wounds of honey bee hosts deters Varroa mites from invading. For Varroa mites, they submerge in the larval food of a L4 larvae after invasion. Thus, we are unsure if they too are able to produce these volatiles while being submerged. It is also unlikely that the mites are competing for food or space since infestations by both mites were generally low and that brood was available for infestation. We found that both mite species reproduced similarly when introduced together in the same brood cell. This reproductive fecundity of T. mercedesae may contribute to their higher prevalence, an indication of increased virulence of this mite species for A. mellifera colonies in Thailand. Also, possible infections from other pathogens vectored by Tropilaelap s, e.g., DWV virus (Dainat et al. 2009; Khongphinitbunjong et al. 2015), that can have synergistic effects on the overall health of infested colonies should be of consideration for further studies.

\section{ACKNOWLEDGMENTS}

We acknowledge the Thailand research fund (BRG 5580013), and the Graduate School of Chiang Mai University, Ph.D. Program, for financial support. We also thank the Agricultural Extension and Development Center, Chiang Mai, for providing honey bee colonies and apiary space.

Prévalence et reproduction de Tropilaelaps mercedesae et Varroa destructor dans des colonies d 'Apis mellifera infestées simultanément

Apidae / abeilles / acariens / infestation simultanée / abondance saisonnière / Thaillande

Verbreitung und Fortpflanzung von Tropilaelaps mercedesae und Varroa destructor in gleichzeitig befallenen Völkern von Apis mellifera

Apidae / Honigbiene / Milben / gleichzeitiger Befall / saisonale Häufigkeit / Thailand

\section{REFERENCES}

Anderson, D.L., Morgan, M.J. (2007) Genetic and morphological variation of bee-parasitic Tropilaelaps mites (Acari: Laelapidae): new and re-defined species. Exp. Appl. Acarol. 43, 1-24

Buawangpong, N., Khongphinitbunjong, K., Chantawannakul, P., Burgett, M. (2013) Tropilaelaps mercedesae: does this honey bee brood mite parasite exhibit a sex preference when infesting brood of the adapted host Apis dorsata? J. Apic. Res. 52, 158-159

Burgett, M., Akratanukul, F., Morse, R.A. (1983) Tropilaelaps clareae: a parasite of honey bees in south-east Asia. Bee World 64, 25-28

Burgett, D.M., Royce, L.A., Ibay, L. (1989) Concurrence of the Acarapis species complex (Acari: Tarsonemidae) in a commercial honey-bee apiary in the Pacific Northwest. Exp. Appl. Acarol. 7, 251-255

Dainat, B., Ken, T., Berthoud, H., Neumann, P. (2009) The ectoparasitic mite Tropilaelaps mercedesae (Acari: Laelapidae) as a vector of honeybee viruses. Insectes Soc 56, 40-43

de Guzman, L.I., Burgett, D.M. (1991) Seasonal abundance of the A. mellifera L. ectoparasites Acarapis dorsalis 
Morgenthaler and Acarapis externus Morgenthaler (Acari: Tarsonemidae) in Oregon. Bee Sci 1, 219-224

de Guzman, L.I., Rinderer, T.E., Frake, A.M. (2007) Growth of Varroa destructor (Acari: Varroidae) population in Russian honey bee (Hymenoptera: Apidae) colonies. Ann. Entomol. Soc. Am. 100, 187-195

de Guzman, L.I., Rinderer, T.E., Frake, A.M. (2008) Comparative reproduction of Varroa destructor in different types of Russian and Italian honey bee combs. Exp. Appl. Acarol. 44, 227-238

Delfinado, M.D. (1963) The Mites of the honeybee in South East Asia. J. Apic. Res. 2, 113-114

Fajardo Jr., A.C., Cervancia, C.R. (2004) The growth of the Philippine bee industry. Buzz Philippines 4, 3-17

Fuchs, S., Langenbach, K. (1989) Multiple infestation of Apis mellifera L. brood cells and reproduction in Varroa jacobsoni Oud. Apidologie 20, 257-266

Garrido, C., Rosenkranz, P. (2003) The reproductive program of female Varroa destructor mites is triggered by its host, Apis mellifera. Exp. Appl. Acarol. 31, 269273

Kavinseksan, B., Wongsiri, S., de Guzman, L.I., Rinderer, T.E. (2003) Absence of Tropilaelaps infestation from recent swarms of Apis dorsata in Thailand. J. Apic. Res. 42, 49-50

Kavinseksan, B., Wongsiri, S., Rinderer, T.E., de Guzman, L.I. (2004) Comparison of the hygienic behavior of ARS Russian and commercial honey bee in Thailand. Am. Bee J. 144, 870-872

Khongphinitbunjong, K., de Guzman, L.I., Buawangpong, N., Rinderer, T.E., Frake, A.M., Chantawannakul, P. (2013) Observations on the removal of brood inoculated with Tropilaelaps mercedesae (Mesostigmata: Laelapidae) and the mite's reproductive success in Apis mellifera colonies. Exp. Appl. Acarol. 62, 47-55

Khongphinitbunjong K, de Guzman L.I, Tarver M, Rinderer TE, Chantawannakul P (2015) Interactions of Tropilaelaps mercedesae, honey bee viruses, and immune response in Apis mellifera. J. Apic. Res. In press

Kirrane, M.J., de Guzman, L.I., Rinderer, T.E., Frake, A.M., Wagnitz, J., Whelan, P.M. (2011) Asynchronous development of honey bee host and Varroa destructor (Mesostigmata:Varroidae) influences reproductive potential of mites. J. Econ. Entomol. 104, 1146-1152
Lee, M.L., Park, Y.M., Lee, M.Y., Kim, Y.S., Kim, H.K. (2005) Density distribution of parasitic mites, Varroa destructor Anderson and Trueman and Tropilaelaps clareae Delfinado and Baker on honey bee pupae (Apis mellifera L.) in autumn season in Korea. Korean J Apic. 20, 103-108

Pettis, J.S., Rose, R., Lichtenberg, E.M., Chantawannakul, P., Buawangpong, N., Somana, W., Sukumalanand, P., VanEngelsdorp, D. (2012) A rapid survey technique for Tropilaelaps mite (Mesostigmata: Laelapidae) detection. J. Econ. Entomol. 106, 1535-1544

Rinderer, T.E., de Guzman, L.I., Sylvester, H.A. (2004) Reexamination of the efficacy of a detergent solution for Varroa mite detection. Am Bee J. 144, 560-562

Ritter W, Schneider-Ritter U (1988) Differences in biology and means of controlling Varroa jacobsoni and Tropilaelaps clareae, two novel parasitic mites of Apis mellifera. In: Needham GR, Page RE, DelfinadoBaker M, Bowman CE (eds), Africanized honey bees and bee mites, New York, pp 387-395

Rogers, L.E., Gilbert, R.O., Burgett, M. (1983) Sampling honeybee colonies for brood production: a double sampling technique. J. Apic. Res. 22, 232-241

Sammatoro, D., Gerson, U., Needham, G. (2000) Parasitic mites of honey bees: life history, implications, and impact. Annu. Rev. Entomol. 45, 519-548

Sihag, R.C. (1988) Incidence of Varroa, Euvarroa and Tropilaelaps mites in the colonies of honey bees Apis mellifera L. in Haryana (India). Am Bee J 128, 212213

Waghchoure-Camphor, E.S., Martin, S.J. (2009) Population changes of Tropilaelaps clareae mites in Apis mellifera colonies in Pakistan. J. Apic. Res. 48, 4649. doi:10.3896/IBRA.1.48.1.10

Weiss, M.R. (2006) Defecation behaviour and ecology of insects. Annu. Rev. Entomol. 51, 635-661

Woyke, J. (1987a) Length of successive stages in the development of the mite Tropilaelaps clareae in relation to honeybee brood age. J. Apic. Res. 26, 110-114

Woyke, J. (1987b) Comparative population dynamics of Tropilaelaps clareae and Varroa jacobsoni mites in honeybees. J. Apic. Res. 26, 196-202

Woyke, J. (1989) Change in shape of Tropilaelaps clareae females and the onset of egg laying. J. Apic. Res. 28, 196-200 